\title{
DRUŽBENOGOSPODARSKI RAZVOJ OBMEJNIH OBMOČIJ V SLOVENIJI
}

\author{
Marijan M. Klemenčič*
}

Izvleček

UDK 911.3:33(497.12-04)

Skoraj vsa obmejna območja v Sloveniji zaostajajo v družbeno-gospodarskem razvoju. Osnovni vzrok je v naravnih mejah, po katerih poteka državna meja ter gospodarska nerazvitost območij na drugi strani meje. Ključne besede: Družbenogospodarski razvoj, obmejno območje, Slovenija

\section{Abstract}

UDC 911.3:33(497.12-04)

SOCIO-ECONOMIC DEVELOPMENT OF THE BORDER AREAS IN SLOVENIA

Greater part of the border areas in Slovenia remain behind the average degree of the socio-economic development. The main reason lies in physical obstacles diminishing the contacts between the areas on the both sides of the border as the existence of depressed areas along the border in the neighbouring countries.

Key words: Socio-economic development, border area, Slovenia

\section{UVOD}

Za povojni družbenogospodarski razvoj Slovenije je značilna zelo močna industrializacija. Le-ta ima izredno pomembno vlogo v gospodarski preobrazbi slovenske družbe tudi zaradi tega, ker je nenavadno dolgo ohranjala vlogo industrije kot najmočnejšega gospodarskega sektorja. Omenjena gospodarska struktura in policentrični razvoj sta povzročila dokaj pregledno in enostavno družbenogospodarsko preobrazbo Slovenije, slonečo na občinah kot gospodarsko močno zaključenih enotah.

Osnovni cilj raziskave je bil ugotoviti stopnje povojnega družbenogospodarskega razvoja obmejnih območij v primerjavi z razvojem celotne države.

Poleg tega naj bi analiza potrdila ali ovrgla tezo, da naj bi obmejna lega večine slovenskega ozemlja in precejšnja živahnost prekomejnih tokov, posebno od 60. let dalje, vplivala na družbenogospodarski razvoj obmejnih območij.

Analiza dejavnostne sestave prebivalstva, ki je osnova za ugotavljanje stopenj družbenogospodarskega razvoja, je dopolnitev raziskave za obdobje 1953-1981. (M. Klemenčič, 1989)

\footnotetext{
* Dr., doc., Oddelek za geografijo, Filozofska fakulteta, Aškerčeva 2, 61000 Ljubljana, SLO
} 
Družbenogospodarski razvoj...

Sprememba zaposlitvene sestave aktivnega prebivalstva je neposredni odraz gospodarskih sprememb, ki se $v$ zadnjih desetletjih kažejo v prehodu iz pretežno agrarnega v pretežno industrijsko ter $\mathrm{v}$ postindustrijsko gospodarstvo.

Dejavnostna sestava aktivnega prebivalstva je obravnavana v sklopu treh osnovnih sektorjev: primarnega, sekundarnega in terciarnega, in sicer po občinah. Obravnava po občinah sicer zabriše lokalne razlike, vendar so na drugi strani gospodarsko zaokrožene enote. Močna zgostitev industrije $v$ občinskem središču je izoblikovala občine $v$ prave funkcijske enote najnižje stopnje.

\section{PREVLADUJOČ GOSPODARSKI SEKTOR}

Povojnemu družbenogospodarskemu razvoju lahko zelo enostavno sledimo z izpostavitvijo prevladujočega gospodarskega sektorja. Popisi prebivalstva kažejo naslednji razvoj.

$V$ petdesetih letih je bila slika enostavna: Slovenija je bila razdeljena na industrijski del, ki je obsegal območje industrijskega polmeseca, ter na kmetijski del, ki je zavzemal večji preostali del Slovenije.

Šestdeseta leta so prinesla le manjši spremembi: vključitev škofjeloškega območja v industrijski polmesec in terciarizacijo Koprskega primorja.

V sedemdesetih letih je prišlo do velikopotezne industrializacije večine slovenskega ozemlja ter do širjenja terciarizacije na sežansko in postojnsko območje.

V osemdesetih letih se je zaključila faza industrializacije. Na večini slovenskega ozemlja je prevladoval sekundarni sektor. Zaostajal je agrarni severovzhodni del Slovenije, medtem ko se je ob primorskem jedru terciarizacije pojavilo še osrednjeslovensko na območju ljubljanskih občin.

Devetdeseta leta pomenijo kvaliteten skok v družbenogospodarskem razvoju. Močno so se razširila območja, na katerih prevladuje $\mathrm{v}$ terciarnem sektorju zaposleno prebivalstvo, predvsem v severovzhodni Sloveniji.

\section{RAZVOJNI TIPI OBČIN}

Prehitevanje ali zaostajanje $v$ razvoju je bilo ugotovljeno na sledeči način. Za izhodišče je bilo vzeto načelo razvojnih stopenj družbenogospodarskega razvoja: agrarni fazi sledi sekundarna (industrializacija), tej pa terciarna. Za prehitevanje razvoja morajo biti za občino deleži nižjega razvojnega sektorja nižji, kot je povprečje za državo v določenem popisnem letu. Obratno velja za zaostajanje. 
Slika 1: Prevladujoči gospodarski sektor v občinah R Slovenije Slovenia - Predominant sector by communities

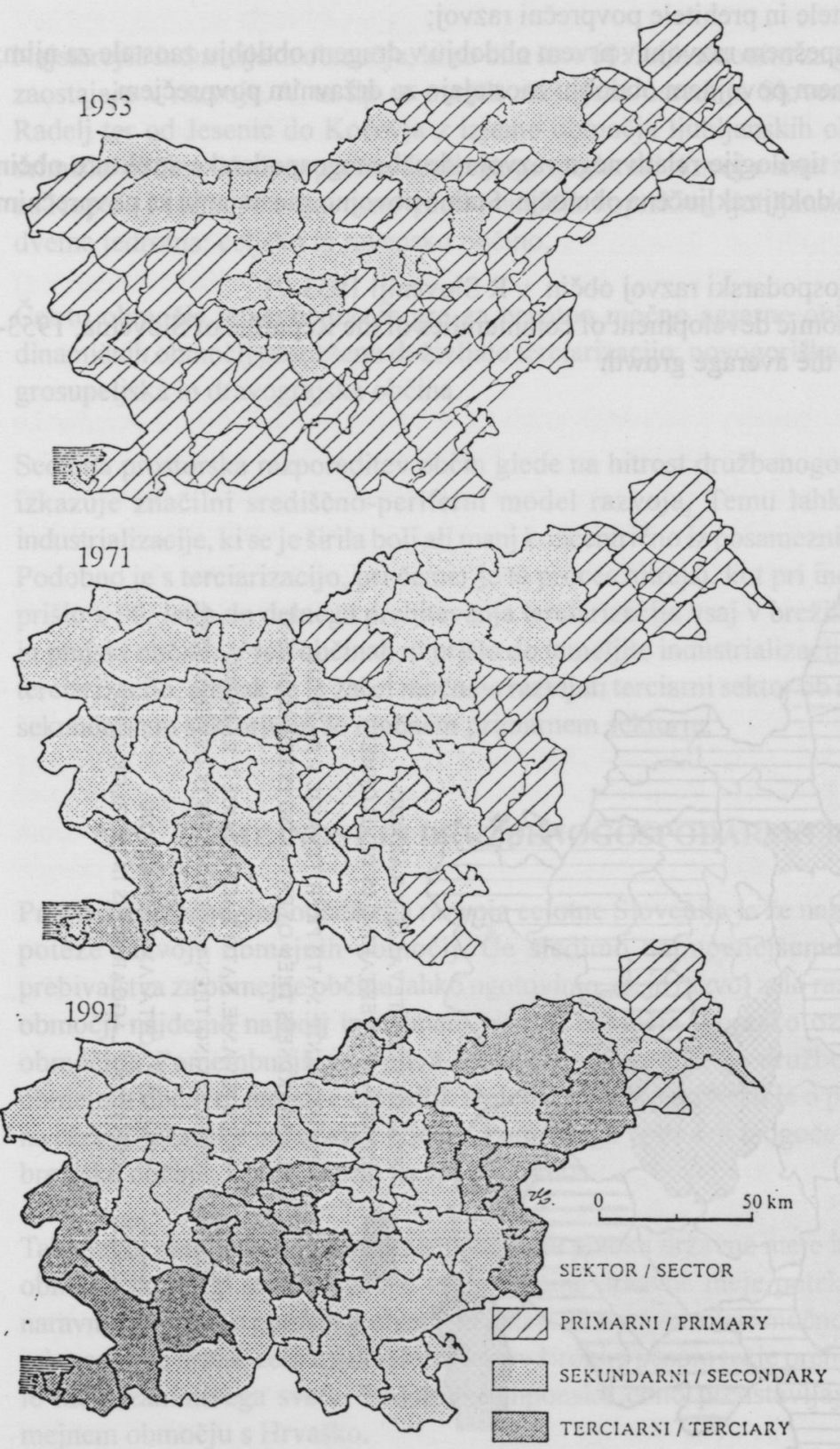


Glede na povprečne vrednosti za vse tri sektorje za celo Slovenijo po povojnih popisih so bile občine razvrščene $\mathrm{v}$ enega od štirih tipov:

1. občine, ki so v vsem obdobju prehitevale povprečni razvoj;

2. občine, ki so dohitele in prehitele povprečni razvoj;

3. občine, ki so po uspešnem razvoju v prvem obdobju v drugem obdobju zaostale za njim; 4. občine, ki v celotnem povojnem obdobju zaostajajo za državnim povprečjem.

Na osnovi navedene tipologije relativnega razvoja družbenogospodarske strukture občin Slovenija razpade na dokaj zaključena območja. Stalno povojno zaostajanje za povprečnim

Slika 2: Družbenogospodarski razvoj občin v R Sloveniji 1953-91

Socio-economic development of communities of the Republic of Slovenia, 19531991 , as to the average growth
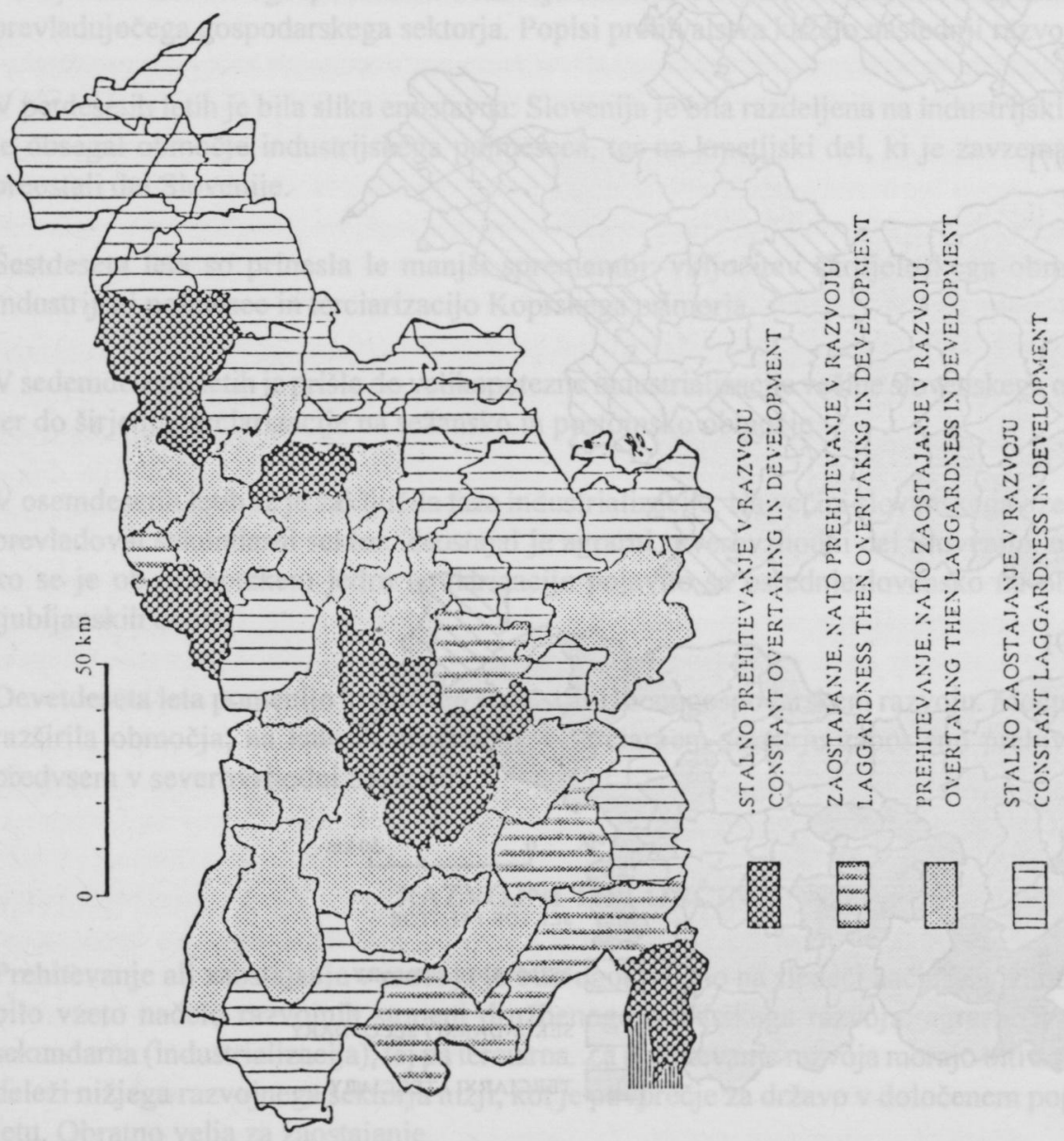
razvojem doživlja širše obmejno območje severovzhodne, vzhodne in jugovzhodne Slovenije. V ta tip spadajo še štiri obmejne in gospodarsko slabo razvite občine: Ribnica, Ilirska Bistrica, Tolmin in Mozirje.

Najstarejša industrijska območja, ki so bila še $v 60$. letih sinonim za gospodarsko razvitost, zaostajajo v razvoju. V ta tip se uvršča razširjena osrednja Slovenija od Ajdovščine do Radelj ter od Jesenic do Kočevja z izjemo območja ljubljanskih občin ter domžalske in vrhniške občine. Nadpovprečen družbenogospodarski razvoj v smeri terciarizacije doživlja os Koper - Maribor s tremi osnovnimi območji: koprskim, ljubljanskim in mariborskim ter dvema jedroma: celjsko in ravensko občino.

Četrto območje je prehodno in gre za prvotno močno agrarne občine, ki zaradi bližine dinamičnih območij pospešeno doživljajo terciarizacijo: novogoriška, sežanska, postojnska, grosupeljska in dravograjska občina.

Sedanja prostorska razporeditev občin glede na hitrost družbenogospodarske preobrazbe izkazuje značilni središčno-periferni model razvoja. Temu lahko sledimo že v času industrializacije, ki se je širila bolj ali manj koncentrično iz posameznih industrijskih središč. Podobno je s terciarizacijo, pri čemer je ta proces hitrejši, kot pri industrializaciji. Tako je prišlo v 90 . letih do delnega prehitevanja terciarizacije vsaj v brežiški, šmarski, šentjurski in ptujski občini. $V$ teh občinah ni prišlo do temeljite industrializacije, ki bi dala osnovo za terciarizacijo, ampak se je začel močneje razvijati terciarni sektor ob sorazmerno skromnem sekundarnem sektorju in še močnem primarnem sektorju.

\section{OBMEJNOST IN DRUŽBENOGOSPODARSKI RAZVOJ}

Pregled družbenogospodarskega razvoja celotne Slovenije je že nakazal nekatere osnovne poteze razvoja obmejnih območij. Če sledimo najmočnejšemu sektorju po popisih prebivalstva za obmejne občine lahko ugotovimo, da je razvoj zelo različen. Med obmejnimi območji najdemo najbolj in najmanj razvita območja (koprsko oziroma murskosoboško območje). Pomembnejšega vpliva prekomejnih središč na družbenogospodarski razvoj obmejnih občin ni mogoče zaslediti. Deloma bi lahko govorili le o posrednem vplivu Trsta na razvoj sežanske in koprske občine. Podobnega vpliva ni mogoče zaznati celo v primeru brežiške občine, ki leži skoraj na robu Zagreba.

Tak razvoj nam je bolj razumljiv ob pregledu poteka državne meje in značilnosti obmejnih območij na drugi strani državne meje. Večina državne meje poteka po tako imenovanih naravnih mejah, po gorskih grebenih in rekah. Te naravne meje močno razmejujejo Slovenijo od sosednjih držav, celo z nekaj kilometrov širokim pasom težje prehodnega in gospodarsko le malo zanimivega sveta. Podobno tamponsko cono predstavljajo obsežni gozdovi na mejnem območju s Hrvaško. 
Tab. 2: Gospodarska sestava aktivnega prebivalstva Slovenije 1953-1991

Economic structure of active population in Slovenia 1953-1991

\begin{tabular}{lccc}
\hline & primarni sektor & sekundarni s. & terciarni s. \\
\hline 1953 & 53,8 & 28,3 & 17,9 \\
1961 & 39,5 & 37,9 & 22,6 \\
1971 & 27,3 & 46,2 & 26,5 \\
1981 & 14,7 & 49,1 & 36,2 \\
1991 & 13,7 & 40,6 & 45,7 \\
\hline
\end{tabular}

Vir: Podatki Zavoda R Slovenije za statistiko

Na drugi strani so vsa območja v sosednjih državah, ki mejijo na Slovenijo, gospodarsko manj razvita, ali pa vsaj v gospodarskem zastoju. Razumljivo je, da si od takega sosedstva ne moremo obtati večje vzpodbude za razvoj slovenskih obmejnih območij. Ob tem zbledi pomen geopolitičnega položaja Slovenije, na katerega prevečkrat postavljamo prevelike upe, da bo pripomogel k razvoju Slovenije. Dosedanji družbenogospodarski razvoj očitno kaže na to, da je slonel na razvoju notranjega gospodarstva in ni pomembneje izkoriščal geopolitičnega položaja Slovenije.

Zanimiv je primer štirih obmejnih občin: Brežic, Šmarij, Šentjurja in Ptuja, ki so se leta 1991 prebile med občine, $v$ katerih prevladuje terciarni sektor. Vse štiri občine imajo še visok delež aktivnega kmečkega prebivalstva (nad 27\%) in komaj za spoznanje višji delež v sekundarnem sektorju zaposlenega prebivalstva. Tako odpade na terciarni sektor le dobra tretjina aktivnega prebivalstva, razen $v$ brežiški občini, kjer znaša $45 \%$. Ti posebni primeri kažejo, da je $\mathrm{v}$ določenih pogojih možen prehod $\mathrm{v}$ terciarizacijo brez pretirane industrializacije. Če ni čutiti vpliva obmejnosti na spreminjanje vloge gospodarskih sektorjev, naj bi se ta odražala vsaj znotraj terciarnega sektorja. $V$ dobri polovici občin $v$ terciarnem sektorju prevladuje trgovina. V obmejnih občinah so kot najmočnejše zastopane vse dejavnosti znotraj terciarnega sektorja. Tudi regionalna razporeditev posameznih tipov občin ne daje opore za tehtnejše dokaze o večjem vplivu obmejnosti na družbenogospodarsko sestavo občin.

\section{MARGINALIZACIJA OBMEJNIH OBMOČIJ}

Za obmejna območja negativna slika se pokaže tudi ob primerjavi med strukturo zaposlenih po posameznih sektorjih v občinah in med državnim povprečjem. Če ostanemo le pri zadnjem popisu prebivalstva leta 1991, se pokaže naslednja slika. Celotna subpanonska Slovenija severno od Save je izrazito nadpovprečno agrarna. V južni Sloveniji (razen Primorske Slovenije) se prepletata primarni in sekundarni sektor kot nadpovprečno zastopana. Podobno 
je tudi z območjem ob severni in zahodni meji, kjer je izpostavljen predvsem sekundarni sektor.

Več kot očitno je, da so obmejna območja hkrati tudi marginalna v smislu gospodarskega razvoja. Njihova dediščina kot pretežno gospodarsko zaostalih, močno agrarnih območij, ni premagana, saj velika večina obmejnih občin še vedno zaostaja za državnim povprečjem. Izjema je le ožje primorsko območje, ki je izkoristilo spremenjene geografskopolitične razmere po drugi svetovni vojni. Razvila se je Nova Gorica kot nadomestno središče Posočja namesto izgubljene Gorice. Prav tako je bilo treba razviti infrastrukturne potenciale Kopra, da bi se nevtralizirala izguba Trsta. Učinki terciarizacije so bili še hitrejši zaradi slabih (pretežno kraških) naravnih pogojev za kmetijstvo, dolgotrajne gospodarske krize (upadanje pomena Trsta za gravitacijsko zaledje) in slabo razvite industrije, zaradi česar se je precejšen del prebivalstva izselil. Terciarni sektor je tako že v začetni fazi deagrarizacije deloma nadomestil industrijo.

\section{SKLEP}

Podatki o dejavnostni sestavi aktivnega prebivalstva po občinah kažejo, da Slovenija ni izkoristila ugodnega obmejnega položaja za hitrejši družbenogospodarski razvoj obmejnih območij. Nasprotno, skoraj vsa obmejna območja zaostajajo v razvoju za slovenskim povprečjem. Povojni razvoj ima izrazit središčno-periferni značaj. Veliko oviro za hitrejši razvoj obmejnih območij predstavljajo naravne meje (gorske verige, reke, gozdovi), ki prekinjajo intenzivneje poseljeni prostor na obeh straneh meja.

\section{LITERATURA}

Klemenčič, M., 1989, Družbenogospodarski prehod v Sloveniji, Dela 6, Ljubljana, s. 230243.

\section{SOCIO-ECONOMIC DEVELOPMENT OF THE BORDER AREAS IN SLOVENIA}

\section{Summary}

The aim of the research was to establish degrees of socio-economic development in the Slovenian border areas and comparing it with development of entire Slovenia after the second World War.

Regarding the large extension of border areas and the intensive transborder traffic throughout the last thirty years, an important question about the impact of the economic structure 
on the other side of the state border on the socio-economic development of Slovenian border areas arrises.

The research is based on an analysis of the economic structure of the active population in individual communities.

The prevailing economic sector (primary, secondary, tertiary) showed that in the post-war period the Slovenia experienced a transition from the agrarian towards an industrial and into the tertiary phase of the society passing the following stages:

- in the fifties, the secondary sector was predominant in a quarter of communities and the primary sector in the rest of them.

- in the sixties, the tertiary sector began to emerge as a major employer in the communities along the coastas a result of the traffic, trade and touristic development.

- in the seventies, in most communities the secondary sector dominated. In the western part of Slovenia the tertiary sector became the most important one in another two communities more.

- in the eighties, the secondary sector reached the maximum of its regional extent. In some communities of the north-eastern part of Slovenia the primary sector was still predominated. Ter tiary sector prevailed in the centre of the Ljubljana basin.

The socio-economic development reached the highest stage in the nineties. The area with the predominance of the active population employed in the tertiary sector extended.

The actual socio-economic structure of the frontier areas is diverse. Well developed and less developed communities are represented. The analysis could not confirm the hypothesis that highly developed areas on the other side of the border have decisive impact on the change of the socio-economic structure of the border areas in Slovenia.

The reasons for such development are:

- state borders follow natural borders as ranges of mountains, vast forests, and rivers in most cases, and

- the border areas of the neighbouring countries are mostly depressed areas.

The regional development of Slovenia in the post-war period is a typical case of the centralperipheral model where border areas are marginal areas. The coast area is the only exception, taking advantage of the changed geo-political circumstances after World War II , as it developed traffic and transportation routes, enlarged and constructed industrial enterprises and developed tourism. 